\title{
FEATURE
}

\section{The courage to connect}

\author{
Curt Meine
}

$\mathbf{T}$ his summer, the Soil and Water Conservation Society (SWCS) invited me to deliver the keynote lecture at its international conference in Fort Worth, Texas. (The full text of the 2012 Pritchard Lecture is available on the SWCS Web site at http://www.swcs.org/documents/ filelibrary/12ac/2012_Meine_Pritchard_ Lecture_CAFD0AA4FD40F.pdf.)

I felt especially honored given the theme of the conference: "Choosing Conservation: Considering Ecology, Economics, and Ethics." I began my remarks by thanking the SWCS for its courage in highlighting that theme. It is no small challenge to explore the complex connections among these "three Es." To do so is to ask fundamental and often uncomfortable questions of ourselves. It is so much easier to ignore the questions or to fall back on conventional answers.

The theme could not be more timely. To be reminded of that, all one had to do was step outside the conference center in Fort Worth. As in much of the continental United States, it was very hot and dry outside. On the way to the conference, one witnessed it. The effects of extreme heat and drought were evident across the land-in countless stressed farms and desiccated corn fields, in cottonwood leaves turned prematurely yellow, in ponds at half capacity and rivers of sand and gravel, and in animals (domestic and wild) gathered up at whatever water bodies were still standing. The great drought of 2012 was one more wake-up call, one more expression of our precarious condition at this point in time. Our social, economic, and environmental challenges are many, and they are connected, converging, compounding, and synergistic. That is why the theme of the conference was and is so appropriate and so necessary.

The theme ought to feel familiar to all those who work in soil and water conservation. Members of the SWCS have

Curt Meine is senior fellow with Aldo Leopold Foundation and the Center for Humans and Nature, Baraboo, Wisconsin. been connecting ecology, economics, and ethics in their daily work since the dire days of the 1930s, when conservationists went to work to revitalize damaged soils and watersheds across the country.You are the heirs of Hugh Hammond Bennett, who said in 1947, "What a frightful lack of insight, and what terribly false economy it would be, if we did not go ahead with soil conservation" (USDA NRCS 2011). We went ahead. You are the heirs of Aldo Leopold, who said (also in 1947), "Cease being intimidated by the argument that a right action is impossible because it does not yield maximum profits, or that a wrong action is to be condoned because it pays. That philosophy is dead in human relations, and its funeral in land-relations is overdue" (Leopold 1947).

Bennett, Leopold, and their contemporaries faced profoundly sobering realities: the destabilization of entire ecosystems (most notably of course in the persistent blight of the Dust Bowl), for which ecologists and conservationists were unprepared; a Great Depression, for which the economic and policy experts were unprepared; and the looming international catastrophe of World War II, for which ethicists, philosophers, and theologians were unprepared. It may seem a great leap from the local problems of small watersheds in the 1930s to the great continental and global problems of contemporary humankind. However, in taking up the challenge of watershed rehabilitation, our predecessors discovered a fundamental principle in conservation: problems occur when we heedlessly separate, segregate, fragment, and overspecialize; we solve problems by bringing people and knowledge and shared values together.

Our first (and frequently our last) response to our systemic conservation problems is so often to devise a short-term fix, to engineer a change in the land; however, we are slow and reluctant to change ourselves, to make the connections, and to confront and transform the forces that are at the root of our problems. We need to solve, as Wendell Berry has stated, "for

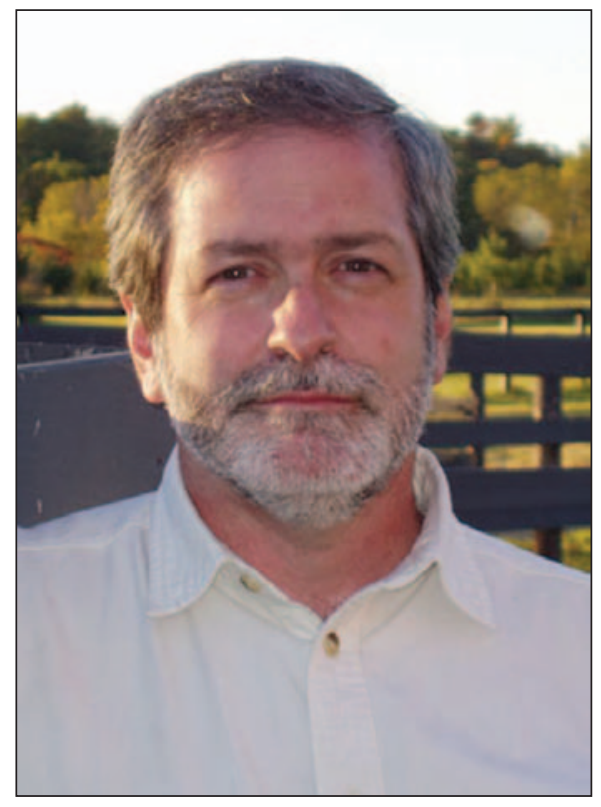

Curt Meine

pattern" (Berry 1981). That is, we cannot treat our varied problems as if they were isolated, separate, disjunct; we must look for the pattern and address it. Perhaps, that defines the difference between a mere silver bullet and an elegant solution. Bennett and Leopold saw the patterns in the landscape and made connections in their heads and in their hearts. They saw that conservation necessarily involves the merging of economic and ethical concerns, and that sound conservation must be informed by critical appreciation, cultural and ecological, of both land and people.

The "three Es" are familiar to us all. Ecology deals with ecological systems, their diversity, function, and resilience. It helps us to see the full context and scope of our conservation challenges. Economics deals with economic systems, and addresses our material needs, wants, and demandsbut has done so as if human beings were the sole source, focus, and measure of value in the universe. Ethics deals with our social systems, our ways of understanding and assigning value, and our experience in sustaining community relationships. Add them together, and it is indeed a complex world we exist in (and that is without even bringing in such necessary and inti- 
mately related concepts as beauty, health, and justice).

Can we bring the three Es together? Can we acknowledge that, in fact, they cannot be separated? It can be argued that conservation itself as a movement has strived to do so for more than a century. The environmental movement made the case, but apparently could not reach the deeper foundations of our conduct, public policy, and economy. Sustainability is our latest term for the effort. The jury is still out on that: whether the sustainability movement will succeed in meaningfully integrating ecology, economics, and ethics, or settle comfortably into an exercise focused mainly on engineering for efficiency and profitability.

If we are to bring our science, our material needs, and our ethics together on the land, then there is no avoiding the point. In the next generation, we must move away from an economy that extracts, depletes, discards, and externalizes its costs as a matter of course, and move toward one that conserves, cultivates, and restores as a fundamental practice and goal. It is a task commensurate with this critical moment in human history and a challenge for the next generation: to build something that has never existed before, a restorative economy. For those in the upcoming generation, there is this small, yet great, comfort: you are not starting from scratch. You stand on the shoulders of, among so many others, Hugh Hammond Bennett and Aldo Leopold. They gave us a precedent. However, they cannot give us what is most required now: the courage to connect. That comes from within.

\section{REFERENCES}

Berry, W. 1981. Solving for pattern. Ch. 9 in The Gift of Good Land: Further Essays Cultural \& Agricultural. San Francisco: North Point Press.

Leopold, A. 1947. The ecological conscience. The Bulletin of the Garden Club of America (Sept 1947):45-53. Reprinted in the Journal of Soil and Water Conservation 3(3):109-112.

USDA NRCS (Natural Resources Conservation Service). 2011. Quotes from Hugh Hammond Bennett. http://www.nrcs.usda.gov/wps/portal/ $\mathrm{nrcs} /$ detail/national/about/history/?\&cid $=\mathrm{nrcs}$ 143_021412. 